\title{
タマネギにおける根端組織由来カルス からの植物体再分化
}

タマネギ (Allium cepa L.) は，重要なネギ類疏菜の一 つとして, 生産量が多い. タマネギの多くは $\mathrm{F}_{1}$ 品種で あり ${ }^{1)}$, 雄性不稔株を利用した種子生産により増殖が行 われているが，種子ょりも更に効率の高い $F_{1}$ 個体の大 量増殖法の開発が望まれている2,3).

Allium 属植物では, ネギ(4やワケギ5,6,7)及びニンニ ク 等の植物でカルスを経由した再分化系がかなり確立 されている.一方, タマネギでは, 鱗葉, 盤茎部からの 再分化植物体の誘導 ${ }^{2,3,9-11)}$, プロトプラストからの球状 胚の誘導 ${ }^{12)}$, 及びタマネギ以外の Allium 属植物とタマ ネギとの雑種からの再分化植物体 ${ }^{13-15)}$ がある.しかし， これらの研究では, 鱗葉及び盤茎部由来カルスからの植 物体再分化の頻度が必ずしも高くなく，再分化培養系が 確立しているとは言えない。このため，タマネギカルス から再分化植物体を高頻度に得るための培養技術の開発 が望まれている。

既に筆者らは，タマネギ種子の初生根先端部よりカル スを誘導し，安定的に増殖させることに成功している ${ }^{16)}$. そこで本研究では, この根端組織由来のカルスを用いて 再分化を試み，効率良く再分化したので報告する.

実験に用いたタマネギは, 栽培品種の中から脱分化能 の優れた $\mathrm{F}_{1}$ 品種 “もみじ”を供試した，カルスの誘導 には， $3 \%$ ショ梼及び $0.2 \%$ ジェランガムに $10 \mu \mathrm{M} \quad 4$ amino-3, 5, 6-trichloropyridine-2-carboxylic acid(以 下 Picloram と略記)及び $1 \mu \mathrm{M}$ 6-furfurylaminopurine (以下 Kinetin と略記) を添加し, $\mathrm{pH} 5.8$ に調整した,

Masatoshi TAKAGI*, Kazunori ToYOI** and Masahiko ICHII**

Plant Regeneration from Onion Root Tip Callus.

* 香川県立高松工芸高等学校 （T760 香川県高松市番町二丁目 9-30）

** 香川大学農学部 (テ761-07 香川県木田郡三木町大字池戸 2393 番地)

* Kagawa Prefectural Takamatsu Kougei High School, Takamatsu, Kagawa 760, Japan

** Faculty of Agriculture, Kagawa University, Miki, Kagawa 761-07, Japan

\section{高儀雅俊*・豊井一徳**・一井㣀比古**}

Murashige and Skoog(以下 MS と略記) ${ }^{17}$ 固体培地を 用いた。この培地上に, 70\%エタノール及び, 有効塩 素濃度約 $3 \%$ のアンチホルミンで滅菌した種子を置床し た. 種子は培地に置床後 3 日目頃から発芽し，カルスは 幼植物体の初生根先端部分からのみ形成された ${ }^{16)}$.この カルスを $10 \mu \mathrm{M}$ Picloram を添加した MS 培地で 60 日間 培養し, 再分化実験に供した。 なおカルスの培養及び再 分化実験は $25^{\circ} \mathrm{C}$ 約 $3000 \mathrm{lux}$ の連続人工照明下で行った.

再分化実験にはオーキシンとして Picloram を, サイ トカイニンとして Kinetin, 6-benzylaminopurine(以下 BA と略記) 及び 6- (2-isopentenyl) aminopurine(以下 2 ip と略記)を添加した MS 培地を用いた。予備実験の結 果から，Picloram及びサイトカイニン濃度はいずれも $0,1,10 \mu \mathrm{M}$ とし, Picloram とサイトカイニンの種類と 濃度を組み合わせた合計 27 区の再分化培地区を設けた。

再分化培地にカルスを置床後 8 週間目に再分化の様子 を観察した，再分化植物体の形状は一般に不定根，不定 芽及び不定胚に分類されるが，本研究でもその形態から 再分化植物体を 3 つに分類して再分化個体を数え，それ を置床カルス数で除してそれぞれの再分化率を求めた。

ホルモンフリー培地及びサイトカイニンのみを添加し た培地では不定根がしばしば観察されたが，Picloram を添加した培地ではサイトカイニンの種類や濃度にかか わらず不定根が殆ど観察されなかった(Table 1). 不定 根の形成率はサイトカイニンの種類や濃度によって異な り, BA, Kinetin, 2 ip のいずれかを $1 \mu \mathrm{M}$ 添加した培地 では約 70\%の不定根形成率を示した，BAまたは Kinetin $10 \mu \mathrm{M}$ 添加した培地では, $1 \mu \mathrm{M}$ 添加した培 地より顕著に形成率が低くなった。一方, 2 ip を $10 \mu \mathrm{M}$ 添加した培地では $1 \mu \mathrm{M}$ 添加した培地とほ浔同じ形成率 を示した.これらのことから，2 ip の方が不定根の再分 化際しては, 変動が少ないと判断される.

不定根はカルス置床後 2 週間目頃から出現し始め, 8 週間目には培地表面を這うように伸長した不定根 (Fig. 1-A)やカルス表面から角状または扇型に伸長した不定 
Table 1. Effect of picloram and cytokinins on regeneration from onion callus culture*1 .

\begin{tabular}{|c|c|c|c|c|c|c|c|}
\hline \multirow{3}{*}{$\begin{array}{l}\text { Picloram } \\
(\mu \mathrm{M})\end{array}$} & \multicolumn{7}{|c|}{ Regeneration rate $^{* 2}(\%)$} \\
\hline & \multirow{2}{*}{0} & \multicolumn{2}{|c|}{$\mathrm{BA}(\mu \mathrm{M})$} & \multicolumn{2}{|c|}{$\operatorname{Kinetin}(\mu \mathrm{M})$} & \multicolumn{2}{|c|}{$2 \operatorname{ip}(\mu \mathrm{M})$} \\
\hline & & 1 & 10 & 1 & 10 & 1 & 10 \\
\hline \multicolumn{8}{|c|}{ Adventitious root formation } \\
\hline 0 & 26 & 68 & 5 & 68 & 5 & 67 & 65 \\
\hline 1 & 1 & 0 & 0 & 0 & 2 & 0 & 0 \\
\hline 10 & 0 & 0 & 0 & 0 & 0 & 0 & 0 \\
\hline \multicolumn{8}{|c|}{ Adventitious bud formation } \\
\hline 0 & 2 & 5 & 15 & 5 & 15 & 65 & 33 \\
\hline 1 & 0 & 0 & 0 & 0 & 0 & 0 & 0 \\
\hline 10 & 0 & 0 & 0 & 0 & 0 & 0 & 0 \\
\hline \multicolumn{8}{|c|}{ Adventitious embryo formation } \\
\hline 0 & 0 & 0 & 0 & 0 & 0 & 67 & 33 \\
\hline 1 & 0 & 0 & 0 & 0 & 0 & 0 & 0 \\
\hline 10 & 0 & 0 & 0 & 0 & 0 & 0 & 0 \\
\hline
\end{tabular}

*1 Observation was made 8 weeks after callus culture.

*2 (Total number of regeneration forming callus/total number of cultured callus) $\times 100$.
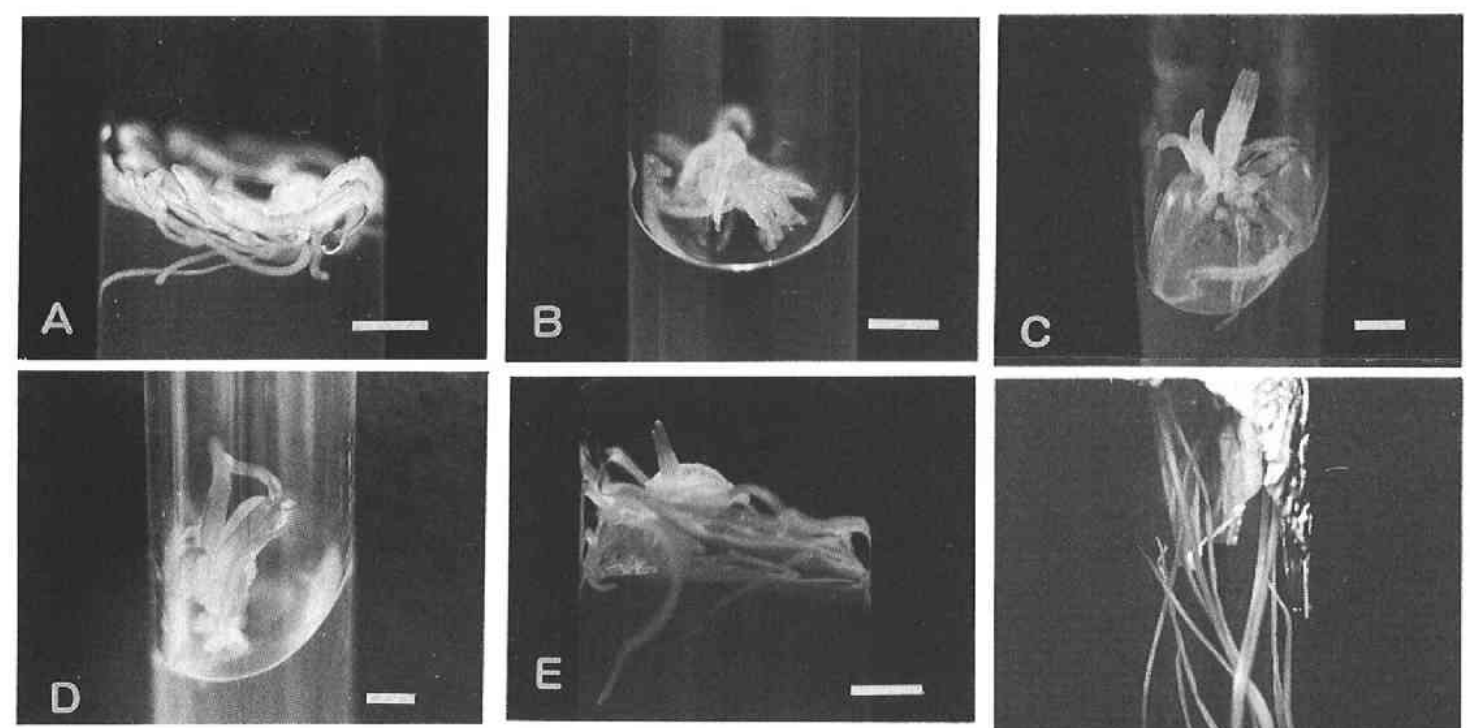

Fig.1 Regenerated roots, buds, embryos and plantlets from root callus of onion.

Roots were observed 5 to 8 weeks after culture on MS medium supplemented with picloram and cytokinins. Buds were observed 6 to 8 weeks after culture on the MS medium supplmented with cytokinins and without picloram. Embryos and plantlets were observed 6 to 8 weeks after culture on the MS medium supplemented with 2 ip.

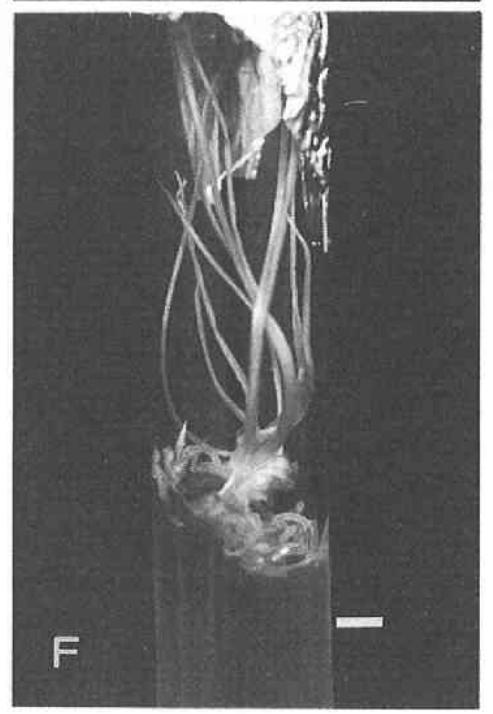

A, B, C: Long, horny and fanlike adventitious roots, respectively. D: Adventitious buds. E: Adventitious embryos. F: Plantlets. (Scale bar indicates $5 \mathrm{~mm}$.) 
根(Fig. 1-B, C)など種々の形態を示した。これらの不 定根はニンジンなどの培㽰時に観察される通常の不定根 とは，形態的に次の点で大いに異なっていた．まず第一 に, 不定根は一般に柔らかいが, 本実験で観察された不 定根は硬く，培地から外しても形状を変えなかった，第 二に，不定根の表面には根毛が形成されておらず，植物 体の根の形状とは異なっていた，本実験ではその形状か ら根と思われるものを不定根とした。 しかしながら，中 島ら ${ }^{3}$ が指摘するとおり，タマネギカルスからの不定根 は embryogenic callus 加ら肧様体へ発達する途中, 何 らかの原因で生長を停止した組織であると推論される. 即ち, 不定根というよりも, むしろ不定根様器官 (root like body)ともいうべきものであると考られる.

ニンジンなどの双子葉植物に比べて，タマネギなどの 単子葉植物では不定胚が棒状であり，また不定泼がカル ス細胞とよく似ているために不定胚経由と不定芽経由と を区別しにくい，そこで根が再分化せずに，芽のみが分 化した場合を不定芽の形成とした(Fig. 1-D).

Picloram を添加すると不定根再分化の場合と同様, 不定芽の形成が殆ど認められなかった(Table 1)，ホル モンフリー培地でも不定芽は観察されたが，サイトカイ ニンを添加することによって不定芽の形成率が増大した。 またサイトカイニンの種類により不定芽の形成率が異な り，2 ip は BA や Kinetinより不定芽の形成を大いに高 めた. 特に $1 \mu \mathrm{M} 2 \mathrm{ip}$ 添加区では $65 \%$ の高い不定芽形 成率を示した。

培養容器内より再分化植物体を取り出し, 同じカルス 塊から芽と根が形成され，かつ両極性があると可視的に 判断できるものを，本実験では不定胚とした ${ }^{33}$.

BA または Kinetin と Picloram との組み合わせを添 加した培地では, 組み合わせの種類やその濃度にかかわ らず，不定胚は観察されなかった。すなわち Picloram を添加せず 2 ip を添加した培地においてのみ，不定胚 及び幼植物体が観察された(Fig. 1-E, F)。この時，1及 び $10 \mu \mathrm{M} 2$ ip 添加区に抢ける不定肧形成率はそれぞれ 67\% 及び 33\%であった(Table 1)。

以上，一連の実験より，タマネギに扔けるカルス経由
の組織培養では，䚬葉及び盤荎部よりも，発芽種子の初 生根先端部を外植物体片として用いた方が，脱分化率が 高くカルスを安定的に供給できる ${ }^{16)}$. さらに, 初生根先 端部由来のカルスは形状がコンパクトであり，鱗葉及び 盤茎部由来のカルスに比べて, 增殖率や形状の安定性に おいて優れている ${ }^{16)}$. 本実験により，このカルスを 1 $\mu \mathrm{M} 2$ ip を含む MS 再分化培地に移すことで, 効率良く 再分化が可能になり，タマネギにおいてカルスを経由し た組織培養系が確立したと考えられる。

$(1996$ 年 4 月 9 日受理)

\section{文献}

1）高橋 尚，1988、ハイテクによる野菜の採種(そ菜種子生 研研究会編), p. 393-396, 誠文堂新光社, 東京.

2）中島寿龟，1987。農業技術，44: 117-121。

3）中島寿龟，桑原宏司，田中政信，1989。佐賀県農試研報， 26: $119-132$.

4）折館寿朗, 1988. 育種学雑誌，38 別 2: 32-33.

5) Shahin, E. A., K. Kaneko, 1986. Hort-Science, 21: 294 -295 .

6）島田恒治，宮崎貞已，田代洋丞，新開隆專博，1973、園 芸学雜誌, 48: 198-199.

7) 島田恒治, 宮崎貞已, 田代洋丞, 新開隆尋博, 1974。園 芸学雑誌, 49: 194-195.

8）大澤勝次，栗山尚志，菅原祐幸，1981，野菜試報 A，9: $1-46$.

9) Phillips, G. C., K. J. Lutein, 1983. Hort-Science, 108 (6) : 943-953.

10）中島寿亀, 桑原宏司, 田中政信, 1989. 園芸学雑誌, 58 (別 2) : 232-233.

11) Nandai, S., G., Fridboring, T. Eriksson, 1977. Hereditas., 85: 57-62.

12）佐藤 裕, 浦上敦子, 永井 信, 1988, 育種学雑誌, 38 (別 2) : 30-31.

13) Lu, C.-C., L. Currah, E. B. Peffley, 1989. Plant Cell Rep., 7: 696-700.

14) van der Valk, P., O. E. Schlten, F. Verstappen, R.C. Jansen, J. J. M. Dons, 1992. Plant Cell, Tissue and Organ Culture, 30: 181-191.

15) Song, P., E. B. Peffley, 1994. Plant Science, 98: 63-68.

16）高儀雅俊，竹村真理，一井真比古，1992，香川大農学報 告, $44(1): 11-17$.

17) Murashige, T., F.Skoog, 1962. Phyol. Plant., 15: 473497. 